\title{
PERLINDUNGAN HAK-HAK PEREMPUAN PASCA PERCERAIAN (STUDI TERHADAP PUTUSAN PENGADILAN AGAMA PALOPO)
}

\author{
Anita Marwing \\ IAIN Palopo \\ Jl. Agatis, Balandai, Kota Palopo, Sulawesi Selatan \\ E-mail: anitamarwing@iainpalopo.ac.id
}

\begin{abstract}
This article aims to determine the women rights in Islam, in post-divorces and in knowing the analysis of judges' decision in Palopo Religious Court regarding the women rights after divorcing. The findings showed that the judge's decision regarding the rights of women were concluded as follows; 1) the contested or talak divorce cases by verdict judgment did not cover the wives rights in which judges presumption should not decide the case on the outside of the charge materials (ultra-petition). So that, the judge did not have the courage to assign or guarantee legally the women rights after divorcing such as Mut'a, child custody, property rights if not being the charge materials. 2) The contested divorce cases did not cover any lawsuit regarding the wives rights. Although the judge had the ex officio rights in determining the wives rights whether requested or not, the judges of Palopo Religious Court were just in case of the cause of divorce where the husband and wife were not willing to be divorced. So, the judges utilized their ex officio rights to punish the husbands for providing Mut'a according to their ability and feasibility. 3) In reconvenes decision, it was clearly mentioned the wives rights in the judges' decision in which they are Iddah living, Mut'ah, past living, and the child costs. At the living Iddah costs, it was decided by Palopo Religious Courts Palopo that it is not in the same nominal amount. It is also similar with the Mut'ah and children costs.
\end{abstract}

Keywords: Women's rights, Divorce, Judge Decision

\begin{abstract}
Abstrak
Artikel ini bertujuan untuk mengetahui hak-hak perempuan dalam Islam, hak-hak perempuan pasca perceraian dan mengetahui analisis putusan hakim Pengadilan Agama Palopo menyangkut hak-hak perempuan pasca perceraian. Hasil penelitian menunjukkan bahwa putusan hakim Pengadilan Agama Palopo menyangkut hak-hak perempuan, disimpulkan sebagai berikut: (1). Kasus perkara cerai gugat maupun cerai talak dengan putusan verstek tidak memuat hak-hak istri, yaitu anggapan hakim tidak boleh memutuskan perkara di luar materi gugatan (ultra petitum) sehingga hakim tidak memiliki keberanian untuk menetapkan/menjamin secara hukum hak-hak perempuan pasca perceraian seperti mut'ah, hak asuh anak, atau hak harta gono gini jika tidak menjadi materi gugatan. (2). Kasus perkara cerai gugat tidak terdapat satupun gugatan mengenai haknya (istri). Meskipun hakim memiliki hak ex oficio dalam menentukan hak-hak perempuan (istri) baik diminta maupun tidak diminta, namun hakim Pengadilan Agama Palopo hanya pada kasus yang penyebab perceraian adalah suami dan istri tidak bersedia diceraikan, maka hakim menggunakan haknya secara ex oficio menghukum suami untuk memberikan mut'ah sesuai dengan kemampuan dan kelayakan. (3). Pada putusan rekonvensi, secara jelas disebutkan hak-hak istri di dalam putusan hakim yaitu nafkah iddah, mut'ah, nafkah lampau, dan biaya anak. Pada biaya nafkah iddah yang diputuskan Pengadilan Agama Palopo pada putusan tersebut, tidak sama jumlah nominalnya. Begitu pula dengan mut'ah dan biaya anak.
\end{abstract}


Kata kunci: Hak perempuan, Perceraian, Putusan Hakim

\section{PENDAHULUAN}

Pada dasarnya perkawinan dilakukan untuk waktu selamanya, sampai matinya salah seorang suami istri. Sebagaimana yang disebutkan dalam Undang-Undang RI Nomor 1 Tahun 1974 tentang perkawinan bahwa tujuan perkawinan adalah membentuk keluarga yang bahagia dan kekal. Hal ini sesuai dengan ajaran Islam. Oleh sebab itu, undang-undang ini menganut prinsip untuk mempersukar terjadinya perceraian. Namun dalam keadaan tertentu terdapat hal-hal yang menghendaki putusnya perkawinan dalam arti bahwa bila perkawinan tetap dilanjutkan, maka kemudharatan akan terjadi. Dalam hal ini, Islam membenarkan putusnya perkawinan sebagai langkah terakhir dari usaha untuk melanjutkan rumah tangga.

Putusnya perkawinan ada dalam beberapa bentuk tergantung dari segi siapa yang berkehendak untuk putusnya perkawinan. Dalam hal ini, ada empat kemungkinan yaitu: ${ }^{1}$

1. Putusnya perkawinan atas kehendak Allah sendiri melalui matinya salah seorang suami istri. Dengan kematian itu dengan sendirinya berakhir pula hubungan perkawinan.

2. Putusnya perkawinan atas kehendak si suami oleh alasan tertentu dan dinyatakan kehendaknya itu dengan ucapan tertentu. Perceraian dalam bentuk ini disebut talaq.

3. Putusnya perkawinan atas kehendak si sitri karena si istri melihat sesuatu yang menghendaki putusnya perkawinan, sedangkan suami tidak berkehendak untuk itu. Kehendak untuk putusnya perkawinan disampaikan si istri dengan cara tertentu ini diterima oleh suami dan dilanjutkan dengan ucapannya untuk memutus perkawinan itu. Putusnya perkawinan dengan cara ini disebut khulu'.

4. Putusnya perkawinan atas kehendak hakim sebagai pihak ketiga setelah melihat adanya sesuatu pada suami dan/atau pada istri yang menandakan tidak dapatnya hubungan perkawinan itu dilanjutkan. Putusnya perkawinan dalam bentuk ini disebut fasakh.

Dengan demikian, regulasi perkawinan di Indonesia tidak hanya memposisikan perempuan menjadi objek perceraian dari pihak suami, tetapi juga bisa menjadi subyek atau inisiator dari sebuah perceraian. Perceraian yang diajukan oleh perempuan atau disebut khulu' diakomodir oleh hukum perkawinan di Indonesia dalam Kompilasi Hukum Islam Pasal 124. Hak khulu' ini diberikan untuk mengakhiri ketidakadilan yang dialami perempuan

1 Amir Syarifuddin, Hukum Perkawinan Islam Di Indonesia: Antara Fiqh Munakahat Dan Undang-Undang Perkawinan, Cet.I (Jakarta: Kencana, 2011).

PALITA: Journal of Social-Religi Research 
dalam bahtera rumah tangga yang tidak harmonis. Istilah khulu' biasanya dikenal dengan istilah cerai gugat.

Fakta menunjukkan bahwa cerai gugat tidak mudah dilakukan dengan capaian keadilan bagi perempuan. Banyak hasil putusan yang mengabulkan gugatan, sementara keadilan yang diinginkan perempuan melalui proses cerai gugat seringkali pupus bahkan berubah menjadi petaka ketika harus kehilangan hak nafkah, terpisahkan dari anak-anak karena hak perwalian dan stigma negatif di masyarakat karena predikat janda yang disandangnya. Kondisi ini seringkali terjadi lantaran keputusan perceraian dalam perkara cerai gugat bukan berada pada inisiatornya tetapi berada dalam pertimbangan hakim. Otoritas hakim menjadi sangat menentukan. Perceraian dan akibat-akibatnya diputuskan berdasarkan kajian dan pertimbangan hakim terhadap kasus melalui tahapan-tahapan dalam persidangan.

Peradilan agama merupakan salah satu sarana yang efektif untuk mewujudkan akses dan kontrol atas hak-hak material maupun non-material yang berkeadilan gender. Pada ranah inilah penelitian terhadap putusan Pengadilan Agama menjadi penting untuk melihat bagaimana hakim sebagai penentu keputusan berempati terhadap perempuan yang haknya sering terabaikan, terutama dalam kasus perceraian. Dengan demikian, artikel ini bertujuan untuk mengetahui bagaimana hak-hak perempuan pasca perceraian dalam Islam, bagaimana tingkat perceraian di Pengadilan Agama Palopo, serta Bagaimana analisis putusan hakim Pengadilan Agama Palopo menyangkut hak-hak perempuan pasca perceraian

\section{PEMBAHASAN}

Beberapa hak-hak Istri setelah terjadi perceraian menurut KHI dan Hukum Islam adalah sebagai berikut:

1. Hak Nafkah, Maskan dan Kiswah

Secara etimologi kata "nafkah"berasal dari bahasa Arab النفقة artinya والانفاق المصروف yaitu biaya, belanja, pengeluaran uang.2 Menurut Amir Syarifuddin, kata nafaqah berasal darikata انفق dalam bahasa Arab secara etimologi mengandung arti: نقص وقل yang berarti hilang atau pergi. ${ }^{3}$

Bila seseorang dikatakan memberikan nafaqah membuat harta yang dimilikinya menjadi sedikit karena telah dilenyapkan atau dipergikannya untuk kepentingan orang lain. Namun apabila kata nafqah ini dihubungkan

${ }^{2}$ Ahmad Warson Munawwir, Kamus Al Munawwir Arab-Indonesia, Cet.XX (Surabaya: Pustaka Progresif, 2002)., h.1449.

${ }^{3}$ Syarifuddin, Hukum Perkawinan Islam Di Indonesia: Antara Fiqh Munakahat Dan Undang-Undang Perkawinan. h. 165. 


\section{8 | Anita Marwing}

dengan perkawinan maka mengandung arti: "sesuatu yang dikeluarkannya dari hartanya untuk kepentingan istrinya sehingga menyebabkan hartanya menjadi berkurang".

Apabila isteri hidup serumah dengan suami, maka suaminya wajib menanggung nafkahnya, mengurus segala kebutuhan, seperti makan, minum, pakaian, tempat tinggal, dan sebagainya. Dalam hal ini, isteri tidak berhak meminta nafkah dalam jumlah tertentu, selama suami melaksanakan kewajibannya itu. Apabila suami bakhil, tidak memberikan nafkah secukupnya kepada isteri tanpa alasan yang benar, maka isteri berhak menuntut jumlah nafkah tertentu baginya untuk keperluan makan, pakaian dan tempat tinggal. Dan hakim boleh memutuskan berapa jumlah nafkah yang harus yang harus diterima oleh isteri, serta mengharuskan suami untuk membayarnya jika tuduhan-tuduhan yang dilontarkan oleh isteri ternyata benar.

\section{Hak Mut'ah}

Kata mut'ah dan dhammah mim (mut'ah) atau kasrah (mit'ah) akar kata dari al-mata', yaitu sesuatu yang disenangi. Maksudnya, materi yang diserahkan suami kepada istri yang dipisahkan dari kehidupannya sebab talaq atau semakna dengan beberapa syarat. Mut'ah wajib diberikan kepada setiap wanita yang dicerai sebelum bercampur dan sebelum kepastian mahar. Pendapat ulama Hanafiyah dan Asy-Syafi'i dalam pendapatnya yang baru (qual jidad). Imam Ahmad yang diriwayakan oleh segolongan ulama telah menjelaskan kewajibannya, yaitu pendapat Ibnu Umar, Ibnu Abbas, AlHasan, Atha' bin Zaid, Az- Zuhri, An-Nukha'i, At-Taswri, dan Ishaq. Sebagian ulama berpendapat bahwa mut'ah dalam kondisi tersebut tidak wajib, ia hanya sunnah. Demikian pendapat Malik, L-Laits, Ibnu Abi Layla, dan Imam Asy-Syafi'i dalam pendapat yang lama (qual qadim).

3. Mahar

Mahar dalam bahasa Arab "shadaq". Asalnya isim mashdar dari kata ashdaqa, mashdarnya ishdaq diambil dari kata shidqin (benar). Dinamakan shadaq memberikan arti benar-benar cinta nikah dan inilah yang pokok dalam kewajiban mahar atau maskawin.

Menurut syara', mahar adalah suatu yang wajib sebab nikah atau bercampur. "Sesuatu yang wajib" kalimat ini bersifat umum, mencakup harta dan manfaat, karena suatu yand ada nilainya atau harganya sah dijadikan mahar. Sebab nikah artinya suatu yang wajib nikah. "Atau bercampur" maksudnya bercampur secara syubhat.

Apabila seorang laki-laki melakukan hubungan dengan seorang wanita yang diduga istrinya atau wanita itu tidur ditempat tidur istri kemudian setelah berhubungan ternyata bukan istrinya tetapi wanita lain. Percampuran seperti ini menggugurkan hukuman dan wajib membayar 
mahar terhadap wanita tersebut sebab serupa dengan percampuran. Demikian juga wajib membayar mahar jika seseorang menikahi wanita dalam akad yang rusak (fasid). Tidak ada bedanya antara berhubungan pada jalan depan atau jalan belakang wanita adam. "Atau luput dilakukan secara paksa", seperti seorang laki-laki berpoligami, salah satunya wanita sudah dewasa dan yang lain wanita bayi yang masih dalam susuan. Istri dewasa menyusui istri yang masih bayi tanpa seizin suami, maka istri bayi menjadi putri suami dalam susuan sehingga haram atasnya. Jika benar, suami wajib membayar separuh mahar yang disebutkan kepada istri bayi kecil. Jika tidak benar, wajib membayar separuh mahar mitsil dan istri dewasa wajib membayar separuh mahar mitsil nya terhadap suami. ${ }^{4}$

4. Biaya Hadhanah Untuk Anak-anak

Hadanah berasal dari kata "Hidhan", artinya lambang. Seperti ungkapan: حَضَنَ الطَّْرْ بَيْضَنَ yang artinya burung itu mengepit telur yang ada dibawah sayapnya. Begitu pula seorang perempuan (ibu) yang mengepit anak-anaknya.

Para ulama fiqih mendefinisikan hadanah, yaitu melakukan pemeliharaan anak yang masih kecil, baik laki-laki maupun perempuan, dan menyediakan sesuatu yang menjadi kebutuhannya, menjaganya dari sesuatu yang menyakiti dan merusak dirinya baik itu mendidik jasmani, rohani, dan akalnya agar mampu berdiri sendiri menghadapi hidup dan memikul tanggung jawabnya. Dengan demikian, mengasuh artinya memelihara atau mendidik. Maksudnya adalah mendidik dan mengasuh anak-anak yang belum dapat membedakan antara yang baik dan yang buruk, belum pandai menggunakan pakaian dan bersuci sendiri dan sebagainya hukumnya wajib, sebab mengabaikannya berarti menghadapkan anak-anak yang masih kecil kepada bahaya kebinasaan.

Hadanah merupakan hak bagi anak-anak yang masih kecil, karena membutuhkan pengawasan, penjagaan, pelaksanaan urusannya dan orang yang mendidiknya. Ibunyalah yang berkewajiban melakukan hadhanah. Anak yang masih kecil memiliki hak hadanah. Karena itu, ibunya diharuskan melakukannya jika mereka membutuhkannya dan tidak ada orang yang lain yang bisa melakukannya. Hal ini dimaksudkan agar hak anak atas pemeliharaan dan pendidikannya tersia-siakan. Jika hadhanahnya dapat ditangani oleh orang lain, misalnya bibi perempuan ia rela melakukannya, sedangkan ibunya tidak mau, maka hak ibu untuk mengasuh menjadi gugur dengan sebab bibi perempuan yang mengasuhnya pun mempunyai hak hadanah (mengasuh). 


\section{0 | Anita Marwing}

Apabila terjadi perceraian, selama ibunya belum menikah lagi, maka ibu diutamakan untuk mengasuhnya, sebab dia lebih mengetahui dan lebih mempu mendidiknya. Juga karena ibu mempunyai rasa kesabaran untuk melakukan tugas ini yang tidak dimiliki oleh bapaknya.

Hak-hak istri pasca perceraian tersebut diatas, sama dengan hak istri pasca perceraian yang disebutkan dalam Pasal 149 KHI bahwa yang menjadi hak istri adalah hak nafkah, mut'ah dan mahar, sedangkan hak hadhanah (pemeliharaan anak) adalah hak dari anak itu sendiri yang mana hak tersebut diterimanya sampai ia mumayyiz berumur sebelum 21 tahun.

Pengadilan Agama memiliki kontribusi penting dalam mempengaruhi dan membentuk praktik dan kebiasaan yang terjadi dalam hubungan hukum antara laki laki dan perempuan. Hal ini karena hampir semua kompleksitas persoalan relasi antara laki-laki dan perempuan sebagai sepasang suami istri adalah bagian pokok dari kompetensi peradilan agama. Peradilan agama dengan demikian merupakan salah satu sarana yang efektif untuk mewujudkan akses dan kontrol atas hak-hak material maupun non-material yang berkeadilan jender. Perkembangan mutakhir berkenaan dengan Peradilan Agama adalah upaya struktural untuk beranjak tak terbatas sebagai pengadilan keluarga. Hal ini antara lain ditandai dengan lahirnya ketentuan baru tentang perluasan cakupan yurisdiksi peradilan agama sebagaimana terdapat dalam UU No. 3 Tahun 2006 tentang Perubahan UU No. 7 Tahun 1989 tentang Peradilan Agama, yang kemudian diperbarui lagi dengan UU No. 50 Tahun 2008. Sebelum tahun 2006, yurisdiksi PA hanya meliputi masalah-masalah keluarga. Dengan lahirnya UU No. 3 Tahun 2006, kompetensi absolut PA merambah ranah perekonomian syariah. ${ }^{5}$

Dengan pertambahan yurisdiksi semacam ini, Pengadilan Agama di Indonesia tidak lagi menjadi pengadilan keluarga tetapi berkembang ke arah pengadilan sipil khusus bagi umat Islam. Bahkan untuk mahkamah syariyyah NAD, wilayah yuridiksinya tidak hanya terbatas pada perdata khusus, namun juga mencakup pelanggaran pidana ringan (jinayah) seperti berjudi, minuman keras, dan berkhalwat. 6

Kewenangan peradilan agama di bidang perkawinan, salah satunya adalah menyangkut perceraian. Dalam situasi perkawinan yang tidak kunjung mendatangkan ketenangan dan kasih saying, ajaran Islam memberikan jalan keluar melalui talak (perceraian) sebagai alternatif

${ }^{5}$ Yang termasuk dalam perkara ekonomi syariah adalah seperti: bank syariah, lembaga keuangan mikro syariah, asuransi syariah reasuransi syariah, reksadana syariah, obligasi syariah dan surat berharga berjangka menengah syariah, sekuritas syariah, pembiayaan syariah, pegadaian syariah, dana pensiun lembaga keuangan syariah dan bisnis syariah. Lihat penjelasan Umum UU No 3 Tahun 2006.

6UU No. 18 Tahun 2001 tentang Nanggroe Aceh Darussalam dan diperteguh dengan UU No. 11 tahun 2006 tentang Pemerintahan Aceh.

\section{PALITA: Journal of Social-Religi Research}


pembebasan manusia dari kehidupan rumah tangga yang tidak sejalan dengan cita-cita luhur perkawinan. ${ }^{7}$

Pengadilan Agama Palopo pada bulan Januari sampai September tahun 2015, masih menunjukkan gejala yang sama. Pengadilan Agama Kota Palopo telah memutus 443 perkara perceraian. Adapun perkara perceraian yang

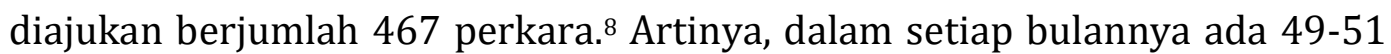
perkara perceraian yang diajukan ataupun diputus oleh majelis hakim Pengadilan Agama Kota Palopo.

Perceraian yang terjadi di pengadilan, ada 2 (dua) kategori yaitu cerai talak dan cerai gugat. Cerai talak adalah permohonan yang diajukan oleh pihak suami ke pengadilan untuk bercerai dengan pihak istri. Adapun cerai gugat adalah putusnya perkawinan atas gugatan istri untuk cerai dengan suaminya yang diajukan ke pengadilan dan pengadilan yang memutuskan perceraian tersebut. ${ }^{9}$

Tabel 1

\begin{tabular}{|c|c|c|c|c|}
\hline No & Bulan & Cerai Talak & Cerai Gugat & Jumlah \\
\hline 1. & Januari & 11 & 41 & 52 \\
\hline 2. & Februari & 17 & 31 & 48 \\
\hline 3. & Maret & 16 & 35 & 51 \\
\hline 4. & April & 15 & 37 & 52 \\
\hline 5. & Mei & 15 & 40 & 54 \\
\hline 6. & Juni & 14 & 31 & 45 \\
\hline 7. & Juli & 14 & 21 & 35 \\
\hline 8. & Agustus & 20 & 56 & 76 \\
\hline 9. & September & 15 & 39 & 54 \\
\hline & JUMLAH & 137 & 331 & 467 \\
\hline
\end{tabular}

Penyebab terjadinya kasus cerai gugat terdapat beragam alasan di antaranya adalah persoalan ekonomi, perselingkuhan, KDRT, Poligami, dan lain sebagainya. Penyebab-penyebab ini bukan penyebab tunggal dalam satu perkara. Kasus cerai gugat akibat KDRT misalnya, KDRT adalah akumulasi dari perseteruan yang tak berujung (syiqaq) akibat suami tidak bertanggung jawab secara ekonomi, bermalas-malasan tak ada usaha, dan berpisah dalam waktu yang lama. Artinya, dalam satu perkara cerai gugat, penyebabnya tidak

${ }^{7}$ Siti Musdah Mulia, Muslimah Reformis: Perempuan Pembaru Keagamaan (Bandung: Penerbit Mizan, 2004)., h.55

${ }^{8}$ Data berasal dari Tabel Registrasi Perkara di bagian Kepaniteraan Pengadilan Agama Kota Palopo Tahun 2015.

${ }^{9}$ M.Yahya Harahap, Kedudukan Warga Negara Dan Acara Peradilan Agama (Jakarta: Pustaka Kartini, 1997)., h. 252. 


\section{2 | Anita Marwing}

tunggal namun akumulasi dari banyak sebab. Namun secara umum, perceraian itu menjadi pilihan lantaran tidak ada lagi kecocokan antara suami istri dan tidak ditemukan lagi solusi untuk tetap hidup rukun dan damai.

Hak-hak perempuan pasca perceraian adalah: (1). Nafkah Iddah, (2). Mut'ah, (3). Nafkah Lampau, (4). Pembagian harta bersama, (5). Hadhanah, (6). Nafkah anak 10. Sementara itu, putusan Pengadilan Agama Palopo menyangkut hak perempuan pasca perceraian, diantaranya dapat dilihat sebagai berikut:

1. Putusan PA Palopo Nomor 384/ Pdt.G/ 2015/ PA. Plp.

Amar putusan:

a. Menyatakan Tergugat yang telah dipanggil secara resmi dan patut untuk menghadap di persidangan, tidak hadir.

b. Mengabulkan gugatan Penggugat dengan verstek.

c. Menjatuhkan talak satu bain shugra Tergugat terhadap Penggugat.

d. Memerintahkan Panitera untuk menyampaikan salinan putusan ini kepada Pegawai Pencatat Nikah Kantor Urusan Agama Kecamatan Kecamatan Walenrang Utara, Kabupaten Luwu dan Kecamatan Bara Kota Palopo dalam jangka waktu paling lambat 30 (tiga puluh) hari sejak putusan ini berkekuatan hukum tetap.

e. Membebankan kepada Penggugat untuk membayar biaya perkara yang hingga kini di ketahui berjumlah Rp. 271,000.00 (dua ratus tujuh puluh satu ribu rupiah).

2. Putusan PA PALOPO Nomor 452/ Pdt.G/ 2015/ PA. Plp. Tahun 2015

Amar putusan:

a. Menyatakan Tergugat yang telah dipanggil secara resmi dan patut untuk menghadap di persidangan, tidak hadir.

b. Mengabulkan gugatan Penggugat dengan verstek.

c. Menjatuhkan talak satu bain shugra Tergugat, $\mathrm{xxx}$ terhadap Penggugat, xxx.

d. Memerintahkan Panitera untuk menyampaikan salinan putusan ini kepada Pegawai Pencatat Nikah Kantor Urusan Agama Kecamatan Bupon Kabupaten Luwu dan Kecamatan Wara Kota Palopo, dalam jangka waktu paling lambat 30 ( tiga puluh ) hari sejak putusan ini berkekuatan hukum tetap.

e. Membebankan kepada Penggugat untuk membayar biaya perkara yang hingga kini di ketahui berjumlah Rp. 271,000.00 (dua ratus tujuh puluh satu ribu rupiah).

3. Putusan PA Palopo Nomor 55/Pdt.G/2015/PA. Plp

\footnotetext{
10Wawancara dengan Abdul Rivai Rinom, S.H, Hakim Pengadilan Agama Palopo, pada tanggal 15 Oktober 2015.
}

PALITA: Journal of Social-Religi Research 
Dalam Konvensi :

a. Mengabulkan permohonan Pemohon;

b. Memberi izin kepada Pemohon (Pemohon) untuk mengikrarkan talak satu raj'i terhadap Termohon (Termohon) di depan Majelis Hakim sidang Pengadilan Agama Palopo;

c. Memerintahkan Panitera Pengadilan Agama Palopo untuk menyampaikan salinan Penetapn Ikrar Talak kepada Pegawai Pencatat Nikah Kantor Urusan Agama Kecamatan Wara, Kota Palopo, jika terjadi perceraian;

Dalam Rekonvensi :

a. Mengabulkan gugatan Penggugat untuk sebagian;

b. Menghukum Tergugat untuk memberikan Penggugat berupa :

1) Uang mut'ah sebesar Rp 2.000.000,- (dua juta rupiah);

2) Uang iddah untuk tiga bulan sebesar Rp 3.000.000,- (tiga juta rupiah);

3) Melunasi hutang Penggugat sebesar Rp 50.000.000,- (lima puluh juta rupiah), dengan angsuran hutang sebesar Rp 2.835.000,- (dua juta delapan ratus tiga puluh lima ribu rupiah) perbulan;

4) Biaya pendidikan untuk anak laki-laki (anak bin Bapak), lahir 22 Agustus 2000, sebesar Rp 500.000,- (lima ratus ribu rupiah) perbulan, sampai anak tersebut dewasa;

c. Tidak menerima dan menolak untuk selain dan selebihnya; Dalam Konvensi dan Rekonvensi: Membebankan kepada Pemohon Konvensi/Tergugat Rekonvensi untuk membayar biaya perkara sejumlah 211.000,- (dua ratus sebelas ribu rupiah)

4. Putusan PA Palopo Nomor 059/Pdt.G/2015/PA. Plp

Dalam Konvensi;

a. Mengabulkan permohonan Pemohon.

b. Memberi izin kepada Pemohon, untuk menjatuhkan talak satu raje'i kepada Termohon, di depan siding Pengadilan Agama Palopo.

c. Memerintahkan kepada Panitera untuk menyampiakn salilan penetapan ikrar talak kepada Pegawai Pencatat Nikah Kantor Urusan Agama Kecamatan Wara Utara, Kecamatan Bara, Kota Palopo dan Kecamatan Walenrang, Kabupaten Luwu setelah Pemohon menjatuhkan talak satu raje'i kepada Termohon.

Dalam Rekonvensi;

a. Mengabulkan gugatan Penggugat sebagian.

b. Menghukum Tergugat untuk membayar kepada Penggugat berupa ;

1) Nafkah anak yang akan datang minimal sebesar Rp. 500,000.00 (lima ratus ribu rupiah) setiap bulan dengan kenaikan $20 \%$ setiap tahun sampai anak tersebut dewasa atau mampu berdiri sendiri. 


\section{4 | Anita Marwing}

2) Nafkah iddah selama 3 (tiga) bulan sebesar Rp. 1,500,000.00 (satu juta lima ratus ribu rupiah).

3) Muth'ah sebesar Rp. 3,000,000.00 (tiga juta rupiah).

4) Nafkah lampau sebesar Rp. 6,000,000.00 (enam juta rupiah).

c. Menghukum kepada Penggugat dan Tergugat untuk membayar utang pada orang tua Penggugat masing-masing sebesar Rp. 18,000,000.00 (delapan belas juta rupiah).

d. Menolak gugatan Penggugat selain dan selebihnya.

Dalam Konvensi dan Rekonvens;

Membebankan Pemohon konvensi/Tergugat rekonvensi untuk membayar biaya perkara yang hingga kini diketahi berjumlah Rp. 271,000.00 (dua ratus tujuh pulu satu ribu rupiah).

5. Putusan PA Palopo Nomor 68/Pdt.G/2015/PA. Plp

Dalam Konvensi;

a. Mengabulkan permohonan Pemohon.

b. Memberi izin kepada Pemohon, untuk menjatuhkan talak satu raje'i kepada Termohon, di depan siding Pengadilan Agama Palopo.

c. Memerintahkan kepada Panitera untuk menyampikan salinan penetapan ikrar talak kepada Pegawai Pencatat Nikah Kantor Urusan Agama Kecamatan Wara, Kota Palopo dan Kecamatan Bua Kabupaten Luwu setelah Pemohon menjatuhkan talak satu raj'i kepada Termohon.

Dalam Rekonvensi;

a. Mengabulkan gugatan Penggugat sebagian.

b. Menghukum Tergugat untuk membayar kepada Penggugat berupa ;

1) Nafkah anak yang akan datang sebesar Rp. 500,000.00 (lima ratus ribu rupiah) setiap bulan sampai anak tersebut dewasa atau mampu berdiri sendiri.

2) Nafkah iddah selama 3 (tiga) bulan sebesar Rp. 1,500,000.00 (satu juta lima ratus ribu rupiah).

3) Muth'ah sebesar Rp. 1,000,000.00 (dua juta rupiah).

4) Nafkah lampau sebesar Rp. 4,000,000.00 (empat juta rupiah).

c. Menolak gugatan Penggugat selain dan selebihnya.

Dalam Konvensi dan Rekonvensi; Membebankan Pemohon konvensi/ Tergugat rekonvensi untuk membayar biaya perkara yang hingga kini diketahi berjumlah Rp. 466,000.00 (empat ratus enam puluh enam ribu rupiah).

6. Putusan PA Palopo Nomor 106/Pdt.G/2015/PA. Plp

Dalam Konvensi:

a. Mengabulkan permohonan Pemohon ; 
b. Menetapkan memberi izin kepada Pemohon, untuk mengucapkan ikrar talak satu raj'i terhadap Termohon, di depan sidang Pengadilan Agama Palopo ;

Dalam Rekonvensi :

a. Mengabulkan gugatan Penggugat sebagian dan menolak selebihnya;

b. Menghukum Tergugat untuk menyerahkan sejumlah uang/barang yang telah disepakati kepada Penggugat berupa:

1) Hak asuh anak bernama jatuh ketangan Penggugat;

2) Nafkah anak yang bernama ..............., sebesar Rp.500.000,00 (lima ratus ribu rupiah) setiap bulan sampai anak tersebut dewasa atau berumur 21 tahun atau telah menikah sebelumnya;

3) Nafkah lampau selama 7 bulan sejumlah Rp. 3.000.000,00 (tiga juta rupiah)

4) Cincin emas 23 karat seberat 2 gram sebagai mahar Penggugat; 2.5 Sepeda motor Jupiter MX Nopol DD 3846 ST;

Dalam Konvensi dan Rekonvensi: Membebankan kepada Pemohon Konvensi/Tergugat Rekonvensi untuk membayar biaya perkara ini sejumlah Rp 346.000,00 (Tiga ratus empat puluh enam ribu rupiah).

7. Putusan PA Palopo Nomor 116/Pdt.G/2015/PA. Plp

Dalam Konvensi :

a. Mengabulkan permohonan Pemohon;

b. Mengizinkan Pemohon untuk menjatuhkan talak satu raj'i terhadap Termohon (Termohon) di depan sidang Pengadilan Agama Palopo;

c. Memerintahkan Panitera Pengadilan Agama Palopo untuk mengirimkan salinan Penetapan ikrar talak kepada Pegawai Pencatat Nikah Kantor urusan Agama Kecamatan Bara dan Kecamatan Wara Utara, Kota Palopo untuk dicatat dalam daftar yang disediakan;

Dalam Rekonvensi :

a. Mengabulkan gugatan penggugat sebagian;

b. Menghukum Tergugat untuk membayar kepada penggugat berupa:

1) Nafkah mut'ah sejumlah Rp. 2.000.000,00 (dua juta rupiah);

2) Nafkah untuk 1 (satu) orang anak dari perkawinan penggugat dan Tergugat sejumlah Rp 1.000.000,00 (satu juta rupiah) perbulan dengan kenaikan $10 \%$ setiap bulan sampai anak tersebut dewasa atau mampu berdiri sendiri;

c. Menolak gugatan penggugat selebihnya;

Dalam Konvensi dan Rekonvensi: Menghukum Pemohon konvensi/Tergugat rekonvensi untuk membayar biaya perkara sejumlah Rp 271.000,00 (dua ratus tujuh puluh satu ribu rupiah);

Dari 7 (tujuh) putusan hakim Pengadilan Agama Palopo di atas, dapat dilihat bahwa putusan hakim Pengadilan Agama Palopo pada point 1 (satu) 


\section{6 | Anita Marwing}

dan 2 (dua) adalah putusan verstek. Putusan verstek adalah putusan yang dijatuhkan karena tergugat/termohon tidak hadir dalam persidangan padahal sudah dipanggil secara resmi, sedangkan penggugat/pemohon hadir.11 Pada putusan verstek tersebut, tidak terdapat putusan yang menyebutkan hak mantan istri. Hal ini disebabkan pihak istri tidak datang pada saat persidangan sampai pada pembacaan hasil putusan. Istri baru dapat mengajukan haknya apabila mengajukan verzeet.

Sedangkan putusan point 3 (tiga) sampai point 7 (tujuh), adalah putusan diklatoir, yaitu putusan yang menyatakan suatu keadaan yang sah menurut hukum. Karena itu, amar putusan diklatoir berbunyi "Menetapkan". Putusan diklatoir terjadi dalam putusan sebagai berikut:

a. Permohonan Thalak.

b. Gugat cerai karena perjanjian ta'lik thalak.

c. Penetapan ahli waris yang sah.

d. Penetapan hak perawatan anak oleh ibunya.

e. Perkara-perkara valunter dan seterusnya.

Pada putusan point 3 sampai 7, terlihat secara jelas disebutkan hak-hak istri di dalam putusan hakim yaitu nafkah iddah, mut'ah, nafkah lampau, dan biaya anak. Pada biaya nafkah iddah yang diputuskan Pengadilan Agama Palopo pada putusan tersebut, tidak sama jumlah nominalnya. Begitu pula dengan mut'ah dan biaya anak. Hal ini disebabkan pertimbangan hakim yang berdasarkan kemampuan ekonomi suami. Oleh sebab itu, hakim dalam putusan penentuan jumlah kadar nafkah iddah, mut'ah dan biaya anak yang harus dibayar oleh suami tidak sama antara putusan satu dengan lainnya.

Hal ini sebagaimana yang diutarakan oleh Ibu Dra. Hj. St. Husnaenah, hakim Pengadilan Agama Palopo bahwa:

"Hal yang menjadi pertimbangan majelis hakim dalam menentukan besaran yang menjadi tanggungan suami terhadap mantan istrinya adalah disesuaikan dengan kemampuan suami, kelayakan dan kepatutan serta dapat terpenuhi kebutuhan hidup anak yang berada di bawah pengasuhan ibunya (mantan istrinya)." 12

Lebih lanjut terkait dengan permasalahan tersebut, ditambahkan pula oleh bapak Drs. H. Misbah, M.H bahwa:

"Hal yang menjadi pertimbangan hakim dalam menentukan besaran yang menjadi tanggungan suami terhadap mantan istrinya selain penghasilan

11Mardani, Hukum Acara Perdata Peradilan Agama, Cet.II (Jakarta: Sinar Grafika, 2010). h. 119.

12Wawancara dengan Dra. Hj. St. Husnaenah, Hakim Pengadilan Agama Palopo, pada tanggal 15 Oktober 2015.

PALITA: Journal of Social-Religi Research 
adalah kebiasaan suami memberi nafkah kepada istri pada saat masih rukun dan biaya hidup yang wajar di daerah tinggal suami istri tersebut."13

Amar putusan pada putusan hakim Pengadilan Agama Palopo pada point 3 sampai 7 adalah putusan kondemnatoir, yang berbunyi "Menghukum". Putusan ini mempunyai kekuatan eksekutorial, yang bila terhukum tidak mau melaksanakan isi putusan secara sukarela, maka atas permohonan penggugat, putusan dapat dilaksanakan dengan paksa (execution force) oleh Pengadilan Agama yang memutusnya. Amar putusan kondemtanoir yang diterapkan di Pengadilan Agama antara lain: a. Penyerahan pembagian harta bersama. b. Penyerahan hak nafkah iddah, mut'ah. c. Penyerahan hak biaya alimentasi anak dan sebagainya.

Ada beberapa kendala dalam mengeksekusi pembebanan nafkah yang telah diputuskan oleh majelis hakim, diantaranya:

a. Mantan suami meninggalkan tempat kediaman

b. Suami tidak mempunyai penghasilan atau tidak menentu penghasilannya

c. Suami tidak mempunyai harta yang ditinggalkan sebagai pengganti nafkah.

Dari putusan tersebu, dapat disimpulkan bahwa amar putusan yang ditetapkan majlis hakim, seluruhnya mengabulkan apa yang menjadi materi gugatan, yaitu menjatuhkan talak ba'in sugra, dan menghukum penggugat untuk membayar biaya perkara. Secara legal formal, apa yang diputuskan majlis hakim sudah sesuai dengan apa yang menjadi materi gugatan. Namun, untuk perkara cerai gugat, hakim tidak bisa memutuskan secara hukum hakhak perempuan pasca perceraian seperti mut'ah, hak asuh anak, atau hak harta gono gini jika tidak menjadi materi gugatan. Oleh sebab itu, majelis hakim Pengadilan Agama Palopo dalam memutus perkara tidak selalu menggunakan haknya secara ex oficio dalam menentukan hak istri diminta atau tidak diminta. Hal ini tergantung pada kasusnya. Kalau penyebab perceraian itu adalah suami dan istri tidak bersedia diceraikan, maka hakim biasanya menggunakan haknya secara ex officio, menghukum suami untuk memberikan mut'ah dan nafkah iddah sesuai dengan kemampuan dan kelayakan. ${ }^{14}$

Dalam perkara cerai gugat, tidak terdapat satu pun kasus dimana istri yang menuntut hak nafkahnya karena tidak ada istri yang mengajukan perceraian dengan alasan nafkah. Apabila istri mengajukan perceraian dengan alasan nafkah dan kemudian hakim mengabulkan pemberian nafkah,

13 Wawancara dengan Drs. H. Misbah, M.H, Hakim Pengadilan Agama Palopo, pada tanggal 15 Oktober 2015.

${ }^{14}$ Wawancara dengan Dra. Hj. St. Husnaenah, Hakim Pengadilan Agama Palopo, pada tanggal 15 Oktober 2015. 


\section{8 | Anita Marwing}

maka alasan istri untuk mengajukan perceraian sudah tidak relevan lagi. Dalam situasi pengetahuan perempuan sebagai litigan masih sangat rendah, maka hampir bisa dipastikan materi gugatan sangat minimal dan pada akhirnya merugikan perempuan. Di sisi lain, kondisi keluarga yang sudah 'tidak sehat' mendorong penggugat untuk segera keluar dari kemelut keluarga, tanpa memikirkan persoalan lain yang ditimbulkan.

Berdasarkan beberapa contoh putusan hakim Pengadilan Agama di atas, dapat disimpulkan bahwa dalam putusan verstek, tidak memuat hakhak istri oleh putusan hakim sesuai dengan pasal 149 KHI. Hakim berprinsip dalam memutuskan suatu kasus putusan cerai thalak berdasarkan keadaan diwaktu persidangan, seperti istri tidak menghadiri persidangan atau materi persidangan tidak tercukupi sehingga dalam kondisi seperti ini bisa dikatakan terabaikan isi dari pasal $149 \mathrm{KHI}$ yang memuat hak-hak istri pasca perceraian yang seharusnya hakim harus melindungi hak-hak istri tersebut. Sehingga dapat dikatakan bahwa dalam putusan verstek, hak istri tidak terlindungi. Hak istri baru dipenuhi dan dilindungi apabila istri mengajukan hak verzeet. Padahal dalam hukum Islam, hak istri itu tidak diklasifikasikan dan dikelompokkan, maka apabila suami menceraikan istrinya, maka istri berhak menerima haknya sesuai dengan firman Allah SWT dalam QS. AlBaqarah (2):223 sebagai berikut:

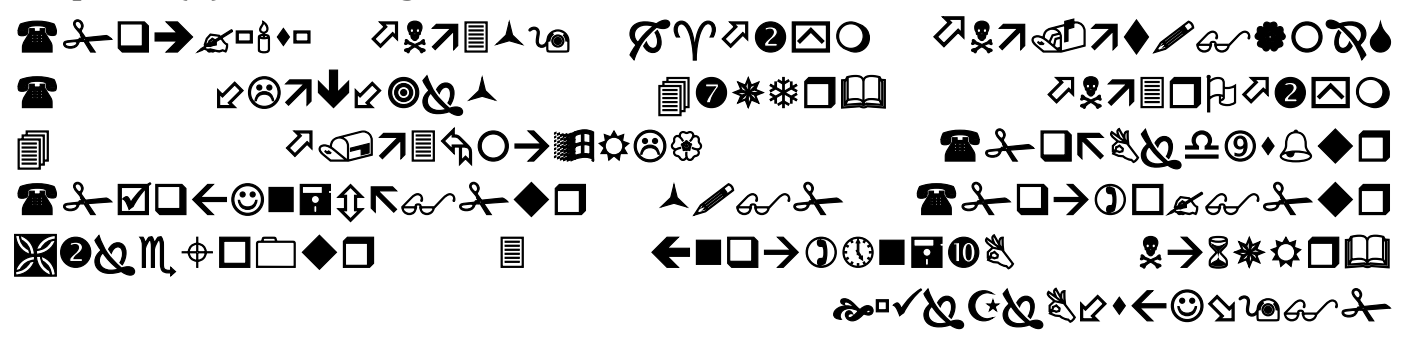

Terjemahnya:

"Isteri-isterimu adalah (seperti) tanah tempat kamu bercocok tanam, Maka datangilah tanah tempat bercocok-tanammu itu bagaimana saja kamu kehendaki. dan kerjakanlah (amal yang baik) untuk dirimu, dan bertakwalah kepada Allah dan ketahuilah bahwa kamu kelak akan menemui-Nya. dan berilah kabar gembira orang-orang yang beriman.

Ada kaidah yang dipegang oleh hakim sehingga pada kasus perkara cerai gugat maupun cerai talak dengan putusan verstek tidak memuat hakhak istri, yaitu bahwa hakim tidak boleh memutuskan perkara di luar materi gugatan (ultra petitum) ${ }^{15}$, sehingga hakim tidak memiliki keberanian untuk menetapkan/menjamin secara hukum hak-hak perempuan pasca perceraian seperti mut'ah, hak asuh anak, atau hak harta gono gini jika tidak menjadi materi gugatan. Padahal, dengan putusnya perkawinan, bukan berarti

15Yahya Harahap, Hukum Acara Perdata (Jakarta: Gramedia, 2005)., h.801-803 
masalah kemelut keluarga dapat terselesaikan, namun muncul masalah lain yang lebih pelik terkait dengan hak dan kewajiban pasca perceraian.

Selain itu, ada kelenturan dalam kaidah ini jika dikaitkan dengan prinsip ex aequo et bono, yang biasanya termaktub dalam tuntutan subsidair. Apabila Pengadilan Agama berpendapat lain, mohon perkara ini diputus menurut hukum dengan seadil-adilnya'. Artinya, prinsip ini memberikan keleluasaan bagi para hakim untuk menggali hukum seluas-luasnya demi menegakkan keadilan. Karena bagaimanapun hakim bukan semata-mata corong UU, namun juga sebagai penafsir dan penemu hukum. Dalam konteks inilah kemampuan hakim untuk menelusuri dan mengungkap fakta hukum menjadi relevan untuk terus digali dan dikembangkan dalam rangka pemberdayaan hakim yang sensitif terhadap nilai-nilai luhur keadilan bukan semata-mata nilai luhur hukum.

Meskipun tindakan ultra petitum yang dilakukan hakim melanggar the principal the rule of law, Mahkamah Agung pernah membuat putusan yang menegaskan bahwa ultra petitum dapat dibenarkan jika masih dalam kerangka yang sejalan dan serasi dengan inti gugatan. ${ }^{16}$ Dalam hal ini, persoalan hak iddah atau hak asuh anak di bawah umur menurut peneliti merupakan hak yang melekat pada perempuan pasca putusnya perkawinan yang dapat diputus sekaligus. Beberapa hakim menuturkan bahwa sesungguhnya hakim secara ex officio karena jabatannya dapat memutus lebih dari apa yang dituntut ligitan jika hakim memandang hal tersebut membawa pada kemaslahatan asalkan putusan penyebab perceraian berasal dari suami.

Dalam persoalan ini, hakim Pengadilan Agama Palopo, lebih berpegang pada pasal 178 ayat (3) HIR, pasal 189 ayat (3) RBG, dan Putusan MA N0. 1001./K/Sip/1972 yang melarang hakim mengabulkan hal-hal yang tidak diminta. Oleh sebab itu, dapat dikatakan bahwa putusan pada kasus perceraian tertentu di Pengadilan Agama Palopo, masih belum melindungi hak-hak perempuan. Selain itu, dalam putusan yang lain sudah memuat hakhak istri dalam bentuk rekonvensi, yang mana hak tersebut harus dipenuhi oleh suami setelah terjadi perceraian. Hak istri dapat dikatakan terpenuhi dan terlindungi, apabila suami melaksanakan putusan tersebut. Akan tetapi, apabila suami tidak menjalani keputusan tersebut maka istri mempunyai hak untuk menuntut pada suami supaya kewajibannya dibayar dengan cara mengajukan ke Pengadilan.

Oleh sebab itu, perlu ada langkah-langkah strategis yang dilakukan agar hak-hak perempuan pasca perceraian dapat dilindungi. Hal ini dapat dilakukan misalnya, langkah pendampingan terhadap ligitan bisa dilakukan

16 Putusan MA N0. 140 K/Sip/1971 sebagaimana dikutip Yahya Harahap, hlm. 802. 


\section{$60 \mid$ Anita Marwing}

pada tahap pengajuan perkara. Pihak yang harus memainkan peranan ini adalah petugas yang menerima pengajuan perkara (meja 1). Dibutuhkan petugas panitera yang memiliki empati dan sensitifitas dalam menghadapi para ligitan yang menumpahkan permasalahan. Untuk selanjutnya mendampingi ligitan dalam merumuskan surat gugatan.

Selain itu, langkah lain yang perlu dilakukan adalah mengoptimalkan posbakum (Pos Bantuan Hukum) di Pengadilan Agama dengan merangkul para advokat, akademisi, LKBH, atau Lembaga Swadaya Masyarakat yang bergelut di ranah pendampingan hukum bagi masyarakat. Pos Bantuan Hukum ini adalah layanan cuma-cuma bagi pencari keadilan untuk mendapatkan pendampingan, konsultasi, dan bantuan hukum.

\section{PENUTUP}

1. Hak-hak perempuan pasca perceraian, diantaranya adalah: mendapatkan mut'ah yang layak baik berupa uang atau benda kecuali mantan istrinya qabla al-dukhul (belum digauli), mendapatkan nafkah, maskan (tempat tinggal), dan kiswah (pakaian), mendapatkan mahar yang masih terutang, mendapatkan biaya hadhanah untuk anak yang belum mencapai 21 tahun.

2. Putusan hakim Pengadilan Agama Palopo menyangkut hak-hak perempuan, dapat disimpulkan sebagai berikut:

a. Kasus perkara cerai gugat maupun cerai talak dengan putusan verstek tidak memuat hak-hak istri, yaitu bahwa hakim tidak boleh memutuskan perkara di luar materi gugatan (ultra petitum) sehingga hakim tidak memiliki keberanian untuk menetapkan/menjamin secara hukum hak-hak perempuan pasca perceraian seperti mut'ah, hak asuh anak, atau hak harta gono gini jika tidak menjadi materi gugatan.

b. Kasus perkara cerai gugat tidak terdapat satupun gugatan mengenai haknya (istri). Meskipun hakim memiliki hak ex oficio dalam menentukan hak-hak perempuan (istri) baik diminta maupun tidak diminta, namun hakim Pengadilan Agama Palopo hanya pada kasus yang penyebab perceraian adalah suami dan istri tidak bersedia diceraikan, maka hakim menggunakan haknya secara ex oficio menghukum suami untuk memberikan mut'ah sesuai dengan kemampuan dan kelayakan.

c. Pada putusan rekonvensi, secara jelas disebutkan hak-hak istri di dalam putusan hakim yaitu nafkah iddah, mut'ah, nafkah lampau, dan biaya anak. Pada biaya nafkah iddah yang diputuskan Pengadilan Agama Palopo pada putusan tersebut, tidak sama jumlah nominalnya. Begitu pula dengan mut'ah dan biaya anak. Hal ini disebabkan pertimbangan hakim yang berdasarkan kemampuan ekonomi suami. Oleh sebab itu, hakim dalam putusan penentuan jumlah kadar nafkah iddah, mut'ah 
dan biaya anak yang harus dibayar oleh suami tidak sama antara putusan satu dengan yang lainnya.

Keterbatasan pengetahuan masyarakat mengenai hak-haknya di muka hukum adalah tanggung jawab bersama. Praktisi hukum, Akademisi, dan masyarakat yang tergabung dalam lembaga swadaya masyarakat harus melakukan pendampingan agar masyarakat, khususnya kaum perempuan mengetahui haknya di muka hukum. Penelitian ini memerlukan penelitian lanjutan berupa aksi pendampingan pada para ligitan dan internalisasi nilainilai kesetaraan gender di kalangan penegak hukum.

\section{DAFTAR PUSTAKA}

Al-Hamdani. Risalah Nikah: Hukum Perkawinan Islam. Jakarta: Amzah, 2002. Alsa, Asmadi. Pendekatan Kuantitatif Dan Kualitatif Serta Kombinasinya Dalam Penelitian Psikologi. Yogyakarta: Pustaka Pelajar, 2007.

Asni. Pembaruan Hukum Islam Di Indonesia: Telaah Epistemologis Kedudukan Perempuan Dalam Hukum Keluarga. Cet.I. Jakarta: Kementerian Agama

RI Direktorat Jenderal Pendidikan Islam Direktorat Pendidikan Tinggi Islam, 2012.

Depdikbud. Kamus Besar Bahasa Indonesia. Cet.2 ed. Jakarta: Balai Pustaka, 1989.

Ghazaly, Abd.Rahman. Fikih Munakahat. Jakarta: Prenadamedia Group, 2003. Hakim, Rahmat. Hukum Perkawinan Islami. Bandung: Pustaka Setia, 2000.

Harahap, M.Yahya. Kedudukan Warga Negara Dan Acara Peradilan Agama. Jakarta: Pustaka Kartini, 1997.

Harahap, Yahya. Hukum Acara Perdata. Jakarta: Gramedia, 2005.

Hawwas, Abdul Wahhab Sayyed. Fiqih Munakahat. Cet.II. Jakarta: Amzah, 2009.

Koentjoro. Berbagai Jenis Inquiry Dalam Penelitian Kualitatif Unpublished Manuscript. Yogyakarta: Fakultas Psikologi Universitas Gadjah Mada, 2007.

Kusuma, Hilman Hadi. Hukum Perkawinan Adat. Bandung: Citra Aditya Bakti, 1999.

Mardani. Hukum Acara Perdata Peradilan Agama. Cet.II. Jakarta: Sinar Grafika, 2010.

Moleong, Lexy J. Metode Penelitian Kualitatif. Bandung: PT. Remaja Rosdakarya, 2007.

Muhammad, Abdulkadir. Hukum Dan Penelitian Hukum. Cet.I. Bandung: PT. Citra Aditya Bakti, 2004.

Mulia, Siti Musdah. Muslimah Reformis: Perempuan Pembaru Keagamaan. Bandung: Penerbit Mizan, 2004. 
Munawwir, Ahmad Warson. Kamus Al Munawwir Arab-Indonesia. Cet.XX. Surabaya: Pustaka Progresif, 2002.

Nur, Djamaan. Fiqih Munakahat. Semarang: Dina Utama, 1993.

Poerwandari, E.Kristi. Pendekatan Kualitatif Dalam Penelitian Psikologi. Jakarta: LPSP3, 1998.

Rasyid, Sulaiman. Fiqih Islam. Bandung: Sinar Baru Argensindo, 1996.

Rofiq, Ahmad. Hukum Islam Di Indonesia. Jakarta: PT. Raja Grafindo Persada, 1995.

Strauss, Anselm, and Corbin Juliet. Dasar-Dasar Penelitian Kualitatif. Yogyakarta: Pustaka Pelajar, 2007.

Sugiyono. Memahami Penelitian Kualitatif. Bandung: CV. Alfabeta, 2008.

Syarifuddin, Amir. Hukum Perkawinan Islam Di Indonesia. Cet.III. Jakarta: Kencana Prenada Media Group, 2009.

- - - Hukum Perkawinan Islam Di Indonesia: Antara Fiqh Munakahat Dan Undang-Undang Perkawinan. Cet.I. Jakarta: Kencana, 2011.

Tihami, M.A, and Sohari Sahrani. Fikih Munakahah Kajian Fikih Nikah Lengkap. Jakarta: Rajawali Press, 2009. 
Sumber Buku:17

17 Asmadi Alsa, Pendekatan Kuantitatif Dan Kualitatif Serta Kombinasinya Dalam Penelitian Psikologi (Yogyakarta: Pustaka Pelajar, 2007); Asni, Pembaruan Hukum Islam Di Indonesia: Telaah Epistemologis Kedudukan Perempuan Dalam Hukum Keluarga, Cet.I (Jakarta: Kementerian Agama RI Direktorat Jenderal Pendidikan Islam Direktorat Pendidikan Tinggi Islam, 2012); Depdikbud, Kamus Besar Bahasa Indonesia, Cet.2 ed. (Jakarta: Balai Pustaka, 1989); Rahmat Hakim, Hukum Perkawinan Islami (Bandung: Pustaka Setia, 2000); Al-Hamdani, Risalah Nikah: Hukum Perkawinan Islam (Jakarta: Amzah, 2002); Abdul Wahhab Sayyed Hawwas, Fiqih Munakahat, Cet.II (Jakarta: Amzah, 2009); Abd.Rahman Ghazaly, Fikih Munakahat (Jakarta: Prenadamedia Group, 2003); Harahap, Kedudukan Warga Negara Dan Acara Peradilan Agama; Harahap, Hukum Acara Perdata; Koentjoro, Berbagai Jenis Inquiry Dalam Penelitian Kualitatif Unpublished Manuscript (Yogyakarta: Fakultas Psikologi Universitas Gadjah Mada, 2007); Hilman Hadi Kusuma, Hukum Perkawinan Adat (Bandung: Citra Aditya Bakti, 1999); Mardani, Hukum Acara Perdata Peradilan Agama; Lexy J Moleong, Metode Penelitian Kualitatif (Bandung: PT. Remaja Rosdakarya, 2007); Abdulkadir Muhammad, Hukum Dan Penelitian Hukum, Cet.I (Bandung: PT. Citra Aditya Bakti, 2004); Mulia, Muslimah Reformis: Perempuan Pembaru Keagamaan; Munawwir, Kamus Al Munawwir ArabIndonesia; Djamaan Nur, Fiqih Munakahat (Semarang: Dina Utama, 1993); E.Kristi Poerwandari, Pendekatan Kualitatif Dalam Penelitian Psikologi (Jakarta: LPSP3, 1998); Sulaiman Rasyid, Fiqih Islam (Bandung: Sinar Baru Argensindo, 1996); Ahmad Rofiq, Hukum Islam Di Indonesia (Jakarta: PT. Raja Grafindo Persada, 1995); Anselm Strauss and Corbin Juliet, Dasar-Dasar Penelitian Kualitatif (Yogyakarta: Pustaka Pelajar, 2007); Amir Syarifuddin, Hukum Perkawinan Islam Di Indonesia, Cet.III (Jakarta: Kencana Prenada Media Group, 2009); Syarifuddin, Hukum Perkawinan Islam Di Indonesia: Antara Fiqh Munakahat Dan Undang-Undang Perkawinan; Sugiyono, Memahami Penelitian Kualitatif (Bandung: CV. Alfabeta, 2008); M.A Tihami and Sohari Sahrani, Fikih Munakahah Kajian Fikih Nikah Lengkap (Jakarta: Rajawali Press, 2009). 